\title{
Immunotherapy with IgY Antibodies toward Outer Membrane Protein F Protects Burned Mice against Pseudomonas aeruginosa Infection
}

\author{
Fatemeh Norouzi, ${ }^{1}$ Bahador Behrouz, ${ }^{1}$ Mahya Ranjbar, ${ }^{1,2}$ \\ and Seyed Latif Mousavi Gargari ${ }^{1}{ }^{1}$ \\ ${ }^{1}$ Department of Biology, Faculty of Basic Science, Shahed University, Tehran, Iran \\ ${ }^{2}$ Department of Microbiology, Shahed University Faculty of Medical Sciences, Tehran, Iran \\ Correspondence should be addressed to Seyed Latif Mousavi Gargari; slmousavi@shahed.ac.ir
}

Received 8 February 2020; Revised 9 April 2020; Accepted 19 May 2020; Published 29 May 2020

Academic Editor: Roberta Antonia Diotti

Copyright (c) 2020 Fatemeh Norouzi et al. This is an open access article distributed under the Creative Commons Attribution License, which permits unrestricted use, distribution, and reproduction in any medium, provided the original work is properly cited.

\begin{abstract}
Burn patients with multidrug-resistant Pseudomonas aeruginosa infections commonly suffer from high morbidity and mortality, which present a major challenge to healthcare systems throughout the world. Outer membrane protein $\mathrm{F}$ (OprF), as a main outer membrane porin, is required for full virulence expression of $P$. aeruginosa. The aim of this study was to evaluate the protective efficacy of egg yolk-specific antibody (IgY) raised against recombinant OprF ( $\mathrm{r}$-OprF) protein in a murine burn model of infection. The hens were immunized with $\mathrm{r}-\mathrm{OppF}$, and anti-r-OprF IgY was purified using salt precipitation. Groups of mice were injected with different regimens of anti-OprF IgY or control IgY (C-IgY). Infections were caused by subcutaneous injection of $P$. aeruginosa strain PAO1 at the burn site. Mice were monitored for mortality for 5 days. The functional activity of anti-OprF IgY was determined by in vitro invasion assays. Immunotherapy with anti-OprF IgY resulted in a significant improvement in the survival of mice infected by P. aeruginosa from $25 \%$ to $87.5 \%$ compared with the C-IgY and PBS. The antiOprF IgY decreased the invasion of $P$. aeruginosa PAO1 into the A549. Passive immunization with anti-OprF IgY led to an efficacious protection against $P$. aeruginosa burn infection in the burn model.
\end{abstract}

\section{Introduction}

$P$. aeruginosa has emerged as a formidable pathogen that contributes to fatal infections among burn patients to a great extent, primarily because they are notoriously resistant to a broad array of antimicrobial agents, which rapidly disseminate throughout the burn units worldwide [1-3]. Moreover, nosocomially acquired multidrug-resistant (MDR) strains of $P$. aeruginosa can spread systemically from the site of burn wound infection to distant organs, in part due to the immunosuppressive effects of burn trauma, in addition to the production of virulence factors that confer invasiveness, which may result in life-threatening systemic infections [4]. The global rising trend of morbidity of burn patients, combined with the dwindling choices of effective therapeutic options to treat MDR $P$. aeruginosa strains, has compelled researchers to investigate the merits of active as well as passive immunotherapy approaches in the treatment of severe burn wound infections.

Most clinical isolates of $P$. aeruginosa possess outer membrane protein $\mathrm{F}(\mathrm{OprF})$, encoded by the oprF gene which maintains the cell shape by anchoring the peptidoglycan to the outer membrane and is involved in host-pathogen interactions and also required for the expression of full virulence $[5,6]$. For instance, studies have shown that non-OprF $P$. aeruginosa mutants have lower virulence in terms of impatience in ExoT and ExoS toxins through the type III secretion system (T3SS), Pseudomonas quinolone signal (PQS) synthesis, and production of the quorum-sensing-dependent virulence factors as well as biofilm development $[7,8]$. 
Mounting evidence from several in vitro and in vivo studies supports the notion that OprF is surface exposed, is antigenically conserved, and could serve as a promising antigen for a vaccine against $P$. aeruginosa in various models of acute and chronic infections [9-13]. In addition, antibodies generated in response to OprF have been shown to exhibit potent antigen-binding, antibody-dependent, and complementmediated opsonophagocytic killing activities against $P$. aeruginosa PAO1 [14], whose anti-OprF IgG activity level is correlated with the level of protection against $P$. aeruginosa in experimental animals and humans $[15,16]$. Moreover, an adenovirus vector expressing OprF induces anti-OprF humoral and cellular immunity and provides protection against a lethal pulmonary challenge with $P$. aeruginosa [12].

Chicken egg yolk immunoglobulins (IgY) have been known as an extremely rich and economical source of polyclonal antibodies, which is not immunologically crossreactive with the mammalian complement system and $\mathrm{IgG}$ [17]. Also, the high yield of specific antibodies along with simple and noninvasive collection method of IgY reveals a number of advantages over mammalian IgG antibodies to control infectious diseases [18]. IgY has been shown to prevent gastrointestinal [19] and influenza virus infections in both humans and animals without side effects [20, 21]. Oral immunotherapy with anti- $P$. aeruginosa IgY antibodies effectively declines chronic colonization of $P$. aeruginosa in CF patients $[22,23]$.

The present study evaluates the protective potential of anti-OprF IgY antibodies against $P$. aeruginosa in the burned mouse model of infection and determines the in vitro protective activity of elicited antibodies.

\section{Materials and Methods}

2.1. Bacterial Strains and Growth Media. P. aeruginosa PAO1 was used for the purification of the OprF protein and challenge. Luria-Bertani (LB) medium, trypticase soy agar (TSA), and tryptic soy broth (TSB; all from Merck, Germany) were used for routine culture of all bacterial strains.

2.2. Animals. Male 6-8-week-old BALB/C mice were purchased from the Royan Institute (Tehran, Iran). The 25 weeks old, shaver laying hens were purchased from a poultry farm (Alborz, Iran). All animal experiments were performed in compliance with the Animal Ethics Committee guidelines of Shahed University.

2.3. Preparation of Recombinant Protein. Recombinant OprF protein was purified as described previously. Briefly, the OprF gene (GenBank Accession No. NC_002516.2), previously cloned into the pET-28a vector, was transformed into Escherichia coli BL21. The recombinant gene construct was expressed with isopropyl b-D thiogalactoside (IPTG, $1 \mathrm{mM}$ ), and protein was affinity purified by a Ni-NTA agarose column under denaturing procedures (Qiagen, Hilden, Germany). The purified recombinant protein was confirmed by Western blotting with mouse anti-His tag monoclonal antibody.
2.4. Preparation of Anti-OprF IgY Antibodies. Two hens were immunized with $150 \mu \mathrm{g}$ of the r-OprF in complete Freund's adjuvant (1:1; Sigma-Aldrich, USA), which was administered intramuscularly and boosted 3 times with $150 \mu \mathrm{g}$ of this protein in incomplete Freund's adjuvant (1:1; SigmaAldrich), while control hen received adjuvant only at 2week intervals. Two weeks after the last injection, the laid eggs were collected daily for 5 to 6 months and stored at $4^{\circ} \mathrm{C}$. Isolation of anti-OprF $\mathrm{IgY}$ antibodies was performed as described previously [24]. The separated egg yolk was diluted 7 times with distilled water ( $\mathrm{pH} 5$ ) and incubated at $-70^{\circ} \mathrm{C}$ overnight and then filtered with Whatman cellulose filter paper (Sigma-Aldrich). The filtrate was mixed with $8.8 \%(w / v) \mathrm{NaCl}$ at $\mathrm{pH} 4$ for $2 \mathrm{~h}$ and then centrifuged at $3,380 \times \mathrm{g}$ for $20 \mathrm{~min}$. The pellet was dissolved in PBS, and final $\operatorname{IgY}$ was stored at $-20^{\circ} \mathrm{C}$. The purity of $\operatorname{IgY}$ was evaluated by $9 \%$ SDS-PAGE, followed by Coomassie Brilliant Blue G-250 staining. The total amount of IgY was quantitatively measured by the Bradford method. The reactivity of IgY antibodies raised against the r-OprF was analyzed by immunoblotting r-OprF. The r-OprF was transferred onto the nitrocellulose membrane from SDS-PAGE by wet transfer blotting apparatus. The membrane was washed by PBS and blocked with PBS containing 5\% $(w / v)$ skim milk overnight. The membrane was washed and incubated with $1 \mathrm{mg}$ of anti-OprF IgY for $2 \mathrm{~h}$ in order to recognize r-OprF. $1: 10000$ diluted rabbit anti-chicken IgY conjugated with HRP (Sigma-Aldrich) was added as a secondary antibody and incubated at $37^{\circ} \mathrm{C}$ for $2 \mathrm{~h}$, then washed with $0.05 \%$ Tween PBS (T-PBS). The paper was submerged in a solution containing $50 \mathrm{mM}$ Tris (pH 7.8) and $0.6 \mathrm{mg} / \mathrm{mL} \mathrm{3,3}{ }^{\prime}$-diaminobenzidine substrate (DAB). The reaction was terminated with distilled water after color development.

2.5. Evaluation of Anti-OprF IgY Titers. Antigen-specific IgY titers against whole-cell $P$. aeruginosa PAO1 as well as $\mathrm{r}$ OprF were assessed by ELISA, as described previously [25]. Briefly, each ELISA plate well (Nunc, USA) was coated with $10^{8} \mathrm{CFU}$ of $P$. aeruginosa $\mathrm{PAO} 1$ or $2.5 \mu \mathrm{g}$ r-OprF in $15 \mathrm{mM}$ $\mathrm{Na}_{2} \mathrm{CO}_{3}$ and $35 \mathrm{mM} \mathrm{NaHCO}_{3}$ (pH 9.6), incubated overnight at $4{ }^{\circ} \mathrm{C}$, washed with $0.05 \%$ T-PBS, and blocked with PBS $+5 \%$ skim milk. $100 \mu \mathrm{L}$ of $50 \mu \mathrm{g} / \mathrm{mL}$ IgY antibodies was incubated in each well for $90 \mathrm{~min}$ at $37^{\circ} \mathrm{C}$ and washed three times with T-PBS, and then, $100 \mu \mathrm{L}$ of $1: 1000$-diluted HRPconjugated rabbit anti-IgY antibody (HRP; Sigma-Aldrich) was added. After incubating for $1 \mathrm{~h}$ at $37^{\circ} \mathrm{C}$, the plates were washed three times with T-PBS. Next, $100 \mu \mathrm{L}$ of TMB liquid substrate was added to each well. After color development for $20 \mathrm{~min}$ at room temperature, the reaction was stopped with $3 \mathrm{~N} \mathrm{H}_{2} \mathrm{SO}_{4}$ and the absorbance at $450 \mathrm{~nm}\left(\mathrm{OD}_{450}\right)$ was measured.

2.6. Invasion Assay. To test the inhibitory activity of antiOprF IgY antibodies on P. aeruginosa invasion to the A549 cell line, a gentamicin protection assay was performed, and we followed the methods of Ranjbar et al. [25]. Briefly, antiOprF IgY antibodies were mixed with PAO1 strain and then added to confluent A549 cells seeded in a 24-well plate (Nunc). Gentamicin was then added to the plate and 


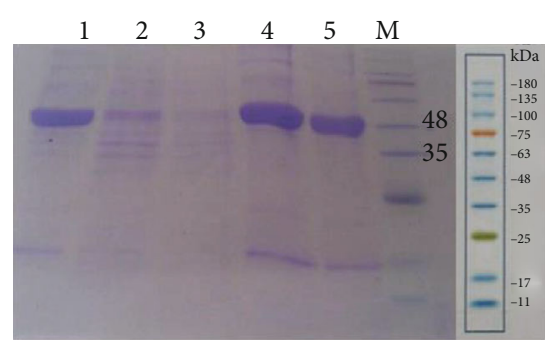

(a)

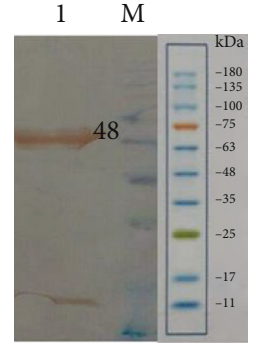

(b)

FIGURE 1: SDS-PAGE for detecting expressed and purified r-OprF. Lane M: low molecular weight protein size markers; Lane 1: precolumn lysate, Lane 2: flow through the matrix; Lane 3: washing with $20 \mathrm{mM}$ imidazole; Lane 4: elution with $250 \mathrm{mM}$ imidazole; Lane 5: purified $\mathrm{r}$-OprF after dialysis (a). Western blotting results. Lane 1: r-OprF detected by monoclonal anti-His tag antibody; Lane M: low molecular weight protein size markers (b).

incubated for $1 \mathrm{~h}$; then, cells were washed with PBS and lysed with $0.5 \%$ Triton X-100, and samples were serially diluted and grown on TSA plates (triplicates). Colony counting after 16 hours showed the number of PAO1 strain released from lysed cells.

2.7. Murine Burn Infection Model. The mice were burned and challenged as previously described by Neely et al. [26]. $\mathrm{BALB} / \mathrm{C}$ mice $(n=56)$ were randomized into 7 groups. Briefly, $10-15 \%$ total body surface area (TBSA) burn wound was created using ethanol flame $(0.5 \mathrm{~mL}$ ethanol). All mice received $0.3 \mathrm{~mL}$ of sterile saline intraperitoneal immediately after burning. Acetaminophen $(0.25 \mathrm{mg} / \mathrm{mL})$ was used post burn as an analgesic. The mice were challenged subcutaneously at the burn site with $P$. aeruginosa neutralized by preincubating with 0.1 and $10 \mathrm{mg}$ of anti-OprF IgY antibodies. In other groups, $P$. aeruginosa were preincubated with $1 \mathrm{mg}$ of anti-OprF IgY antibodies and then mice received intravenously $0.5 \mathrm{mg}$ of anti-OprF IgY antibodies $12 \mathrm{~h}$ after infection. Moreover, in other groups, mice received $1 \mathrm{mg}$ of antiOprF IgY antibodies $2 \mathrm{~h}$ before infection and $0.5 \mathrm{mg}$ of antiOprF IgY antibodies 12 and $24 \mathrm{~h}$ after infection. In the IgY control group, mice were challenged subcutaneously with $P$. aeruginosa that were preincubated $1 \mathrm{~h}$ with $1 \mathrm{mg}$ of control $\operatorname{IgY}(\mathrm{C}-\operatorname{IgY})$. Survival without treatment was monitored in the PBS-treated group. The burn control group comprised untreated mice with burn wounds that were not infected. The survival rate of experimental mice was monitored twice daily up to 5 days, which were analyzed using the MantelCox log-rank test [25].

2.8. Statistical Analysis. All statistical analyses were performed using GraphPad Prism 6 (GraphPad Software, Inc., USA). The data were analyzed by one-way analysis of variance with Tukey's multiple comparison tests. Survival analysis for different mouse groups was performed using the Kaplan Meier survival curve with the Mantel-Cox log-rank test [25]. All results were expressed as the mean \pm standard deviation (SD). The $P$ values less than 0.05 were considered statistically significant.

\section{Results}

3.1. Expression and Purification of $r-O p r F$. The protein expression of E. coli BL21 (DE3) carrying a recombinant vector was induced with IPTG $(1 \mathrm{mM})$. Based on the SDSPAGE, the expression product of $\mathrm{r}$-OprF protein was approximately $48 \mathrm{kDa}$. The OprF was successfully purified by Ni-NTA affinity chromatography under denaturing procedures (Figure 1(a)). As illustrated in Figure 1(b), based on Western blot analysis, anti-His monoclonal antibody reacted specifically with a $\sim 48 \mathrm{kDa}$ purified protein, corresponding to r-OprF.

3.2. The Reactivity and Specificity of IgY Antibodies Raised against OprF. The reactivity and specificity of IgY antibodies were evaluated using immunoblots of OprF. The IgY raised against $\mathrm{r}-\mathrm{OprF}$ was precipitated by $\mathrm{NaCl}$, and $50 \mathrm{mg}$ of anti-OprF IgY was obtained per egg (Figure 2(a)). IgY antibodies from immunized egg yolk reacted with $\sim 48 \mathrm{kDa} \mathrm{r}$ OprF protein (Figure 2(b)). The specificities of IgY antibodies raised against $\mathrm{r}$-OprF were further verified using an indirect ELISA to analyze whole cell lysates as well as r-OprF. As shown in Figures 2(c) and 2(d), the IgY levels of r-OprF-immunized hen against whole live cells of $P$. aeruginosa $\mathrm{PAO} 1$ strain or recombinant protein were significantly $(P<0.01)$ higher than those of C-IgY over a period of time.

3.3. Anti-OprF IgY Antibodies Reduce P. aeruginosa Invasion. Anti-OprF IgY antibodies decrease the invasion to A549 cells by $P$. aeruginosa. The invasion efficiency of PAO1 in the presence of PBS was 100\%. In contrast, in the presence of 1 and $2 \mathrm{mg} / \mathrm{mL}$ of anti-OprF IgY antibodies, invasion efficiencies of PAO1 were $33.72 \%$ and $35.08 \%$, respectively, which were significantly higher than that of controls $(P<0.05$, Figure 3). There was no significant difference between 1 and $2 \mathrm{mg} / \mathrm{mL}$ of anti-OprF $\operatorname{IgY}(P<0.05)$. In the presence of $\mathrm{C}-\operatorname{IgY}$ antibodies, the invasion efficiency of PAO1 was $58.02 \%$, which was significantly higher than that of PBS $(P<0.05)$ (Figure 3). 


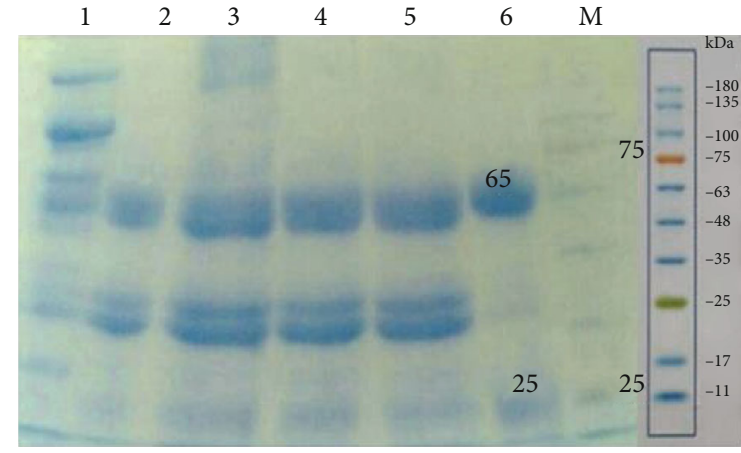

(a)

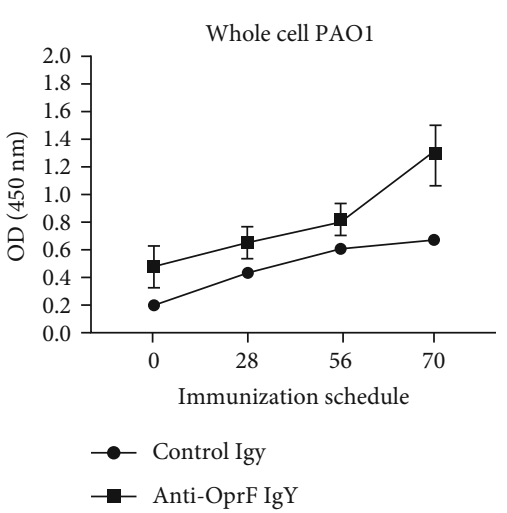

(c)

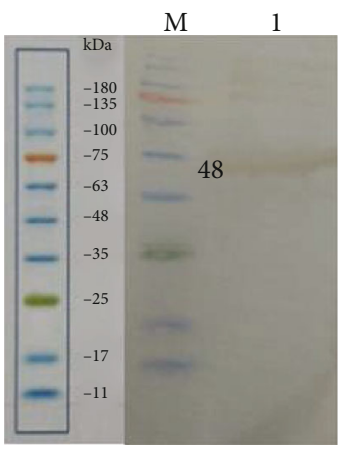

(b)

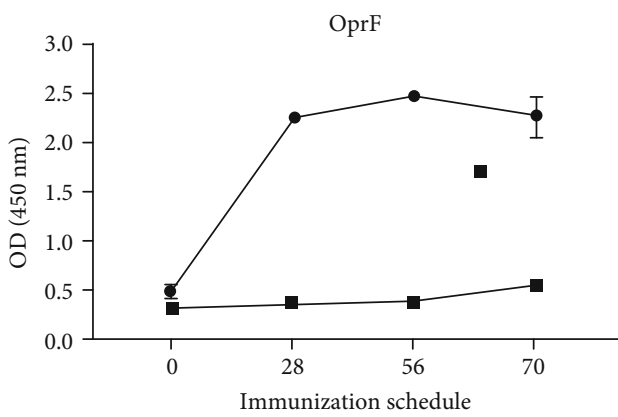

(d)

FIGURE 2: Precipitation and reactivity of anti-OprF IgY antibodies. SDS-PAGE of IgY precipitated with NaCl under acidic conditions. Lane 1: egg yolk; Lane 2: filtered diluted egg yolk, Lane 3: add NaCl; Lane 4: adjust $\mathrm{pH} 4$; Lane 5: precipitated at room temperature for 2 h; Lane 6: purified IgY; Lane M: protein marker (a). R-OprF induced specific IgY binding to $P$. aeruginosa target antigen. IgY immunoreacted with r-OprF ( 48) protein (b). An indirect ELISA was used to determine the reactivity of IgY antibodies against $r$-OprF with $P$. aeruginosa strain PAO1 (c) and r-OprF (d). C-IgY served as negative controls. Values represent the mean of triplicate independent experiments \pm standard deviation (SD).

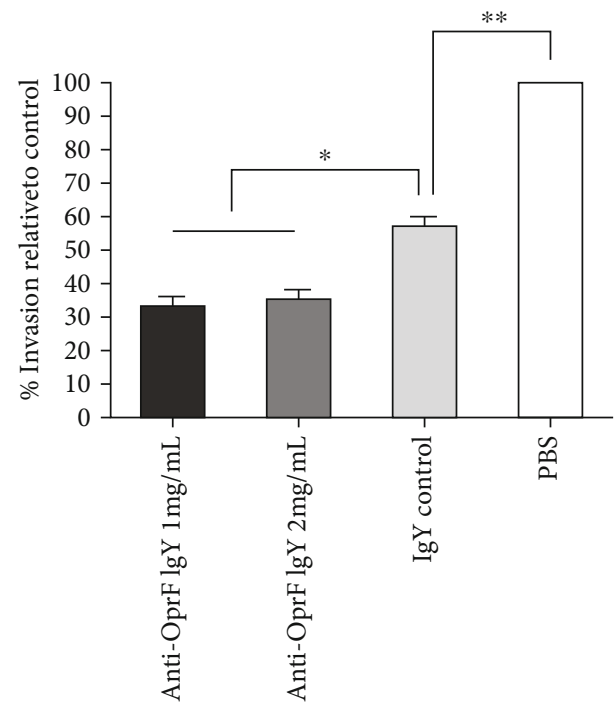

FIGURE 3: The inhibitory effects of anti-OprF IgY antibodies on the invasion of $P$. aeruginosa to A549 cells. PAO1 strain was incubated with different amounts of IgY antibodies ( 1 and $2 \mathrm{mg} / \mathrm{mL}$ ). C-IgY and PBS served as controls. Values represent the mean of triplicate independent experiments \pm SD. ${ }^{*} P<0.05$ and ${ }^{* *} P<0.01$.
3.4. Anti-OprF IgY Antibodies Increased the Survival of P. aeruginosa Infected Mice. To assess the efficacy of antiOprF IgY in rising protection against $P$. aeruginosa infection, we compared the survival rates of passively immunized mice with the anti-OprF IgY versus C-PBS- and C-IgY-infected mice (Table 1). The survival rates of infected mice with neutralized $P$. aeruginosa with both 0.1 and $10 \mathrm{mg}$ of anti-OprF IgY were determined to be $25 \%$ (Figure 4(a)). Moreover, the survival rate of infected mice with neutralized $P$. aeruginosa with $1 \mathrm{mg}$ of anti-OprF IgY and those that received $0.5 \mathrm{mg}$ of anti-OprF IgY intravenously $12 \mathrm{~h}$ after infection was $50 \%$ (Table 1, Figure 4(b)). In addition, the survival rate of infected mice received $1 \mathrm{mg}$ of anti-OprF IgY subcutaneously $2 \mathrm{~h}$ before infection as prophylaxis and treated with $0.5 \mathrm{mg}$ of anti-OprF IgY intravenously 12 and $24 \mathrm{~h}$ after infection was $87.5 \%$. None of the C-PBS and C-IgY mice survived $P$. aeruginosa wound infections (Table 1, Figure 4(c)). All noninfected burned mice survived.

\section{Discussion}

The foremost challenge in controlling $P$. aeruginosa burn wound infections is a limited success in antimicrobial therapy due to the emergence of MDR strains, which are highly 
TABle 1: The effect of different regimens of anti-OprF IgY antibodies on the survival of $P$. aeruginosa-infected mice $(n=8)$. Survival was assessed in infected mice with burn wounds days after subcutaneous injection of $P$. aeruginosa.

\begin{tabular}{|c|c|c|c|c|c|c|c|c|}
\hline \multirow[t]{2}{*}{ Group } & \multirow[t]{2}{*}{ Challenge } & \multirow[t]{2}{*}{ Intravenous treatment } & \multicolumn{5}{|c|}{$\begin{array}{l}\text { No. of dead mice/total } \\
\text { no. of mice on day }\end{array}$} & \multirow[t]{2}{*}{ Survival (\%) } \\
\hline & & & 1 & 2 & 3 & 4 & 5 & \\
\hline I & $\begin{array}{c}\text { Neutralized } P \text {. aeruginosa with } \\
0.1 \mathrm{mg} \text { of anti-OprF IgY }\end{array}$ & - & $1 / 8$ & $6 / 8$ & $6 / 8$ & $6 / 8$ & $6 / 8^{*}$ & 25 \\
\hline II & $\begin{array}{c}\text { Neutralized } P \text {. aeruginosa with } \\
10 \mathrm{mg} \text { of anti-OprF IgY }\end{array}$ & - & $0 / 8$ & $0 / 8$ & $4 / 8$ & $6 / 8$ & $6 / 8^{*}$ & 25 \\
\hline III & $\begin{array}{c}\text { Neutralized } P \text {. aeruginosa with } \\
1 \mathrm{mg} \text { of anti-OprF IgY }\end{array}$ & $\begin{array}{l}0.5 \mathrm{mg} \text { of anti-OprF IgY } \\
(12 \mathrm{~h} \text { after infection) }\end{array}$ & $0 / 8$ & $2 / 8$ & $4 / 8$ & $4 / 8$ & $4 / 8^{* *}$ & 50 \\
\hline IV & $\begin{array}{c}\text { Prophylaxis } 1 \mathrm{mg} \text { of anti-OprF IgY } \\
2 \mathrm{~h} \text { before infection with } P \text {. aeruginosa }\end{array}$ & $\begin{array}{c}0.5 \mathrm{mg} \text { of anti-OprF IgY } \\
(12 \mathrm{~h} \text { and } 24 \mathrm{~h} \text { after infection })\end{array}$ & $0 / 8$ & $0 / 8$ & $1 / 8$ & $1 / 8$ & $1 / 8^{* *}$ & 87.5 \\
\hline $\mathrm{V}$ & $\begin{array}{c}\text { Neutralized } P \text {. aeruginosa with } \\
1 \mathrm{mg} \text { of control IgY }\end{array}$ & - & $0 / 8$ & $6 / 8$ & $8 / 8$ & & & 0 \\
\hline VI & P. aeruginosa & - & $8 / 8$ & & & & & 0 \\
\hline VII & - & - & $0 / 8$ & $0 / 8$ & $0 / 8$ & $0 / 8$ & $0 / 8^{* *}$ & 100 \\
\hline
\end{tabular}

${ }^{*} P<0.05$ and ${ }^{* *} P<0.01$ (Mantel-Cox log-rank test).

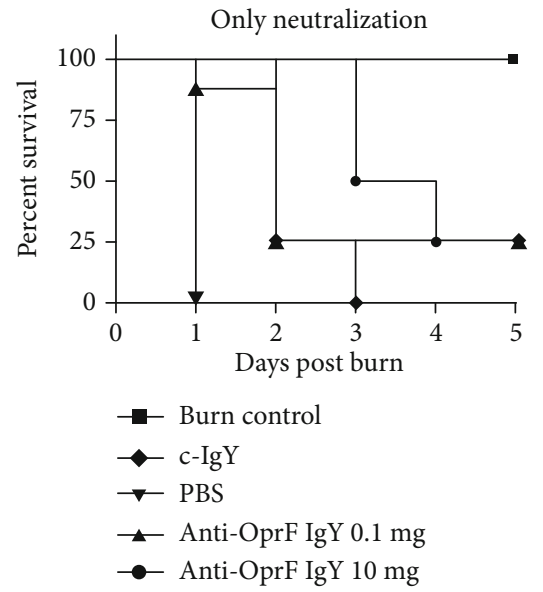

(a)

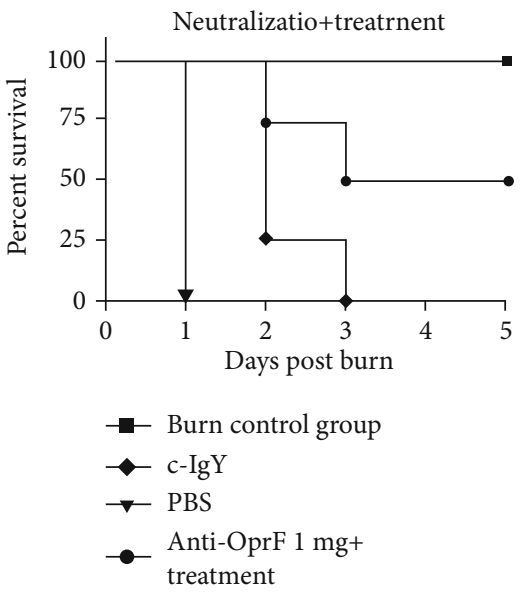

(b)

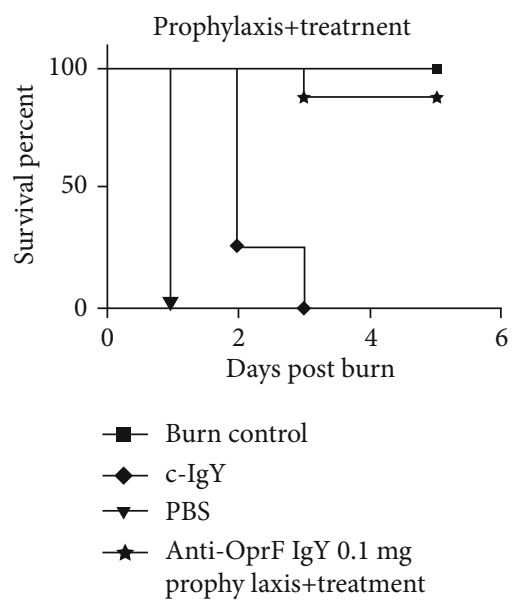

(c)

FIGURE 4: Protective effect of different anti-OprF IgY regimens on the survival of infected mice $(n=8)$ in comparison to control groups 5 days after subcutaneous inoculation of $10^{8} \mathrm{CFU}$ P. aeruginosa. Mice received specific IgY as neutralized with bacteria (a), neutralized with bacteria treated with IgY after $12 \mathrm{~h}(\mathrm{~b})$, and prophylaxis and treatment (c). 
resistant to virtually all available antimicrobial agents. Moreover, $P$. aeruginosa commonly evades the immune response and produces a wide array of virulence factors, which further damages the patient's organ systems. This further complicates patient treatment and leads to the exclusion of antibody-based immunotherapy. Although several $P$. aeruginosa antigens have been evaluated as possible vaccine candidates, OprF is known as a feasible target antigen because it is expressed and conserved antigenically in clinical isolates as well as having important functions during infection and providing protective antibody responses. In the current study, the burn wound mouse model has used to demonstrate that anti-OprF IgY antibodies afford protection against lethal $P$. aeruginosa infections. Our result showed that burned challenged mice were protected and their survival rates were higher than control groups. The results of the burned mouse model indicated that prophylaxis of $P$. aeruginosa infection by anti-OprF IgY antibodies and intravenous injection of anti-OprF IgY antibodies as treatment led to an increase of $87.5 \%$ in the survival rate of mice compared to the control group. Our findings are consistent with Matthews-Greer and Gilleland [5], who showed active immunization with isolated OprF from cell envelope led to an increase of $83 \%$ in the survival rate of burned mice after challenge with $P$. aeruginosa. Additionally, Worgall et al. demonstrated that active immunization with adenovirus expressing $P$. aeruginosa OprF increased the survival rate of infected mice in acute pneumonia model to $80 \%$ [12]. This also accords with our earlier observation where preincubation of P. aeruginosa with anti PcrV IgY enhanced the survival rate of burned mice to $33 \%$ as our $25 \%$ in the same preincubated group [25]. It is crucial to consider this statement, especially in the era of increasing number of drugresistant bacteria and predominant MDR- $P$. aeruginosa strains in numerous hospitals, principally in burn units. In addition, the complex issue of successfully eradicating virulent and highly resistant bacterial strains within burn patients is further exacerbated with the issue of dwindling number of newly approved antimicrobial agents against such strains. Fortunately, mounting evidence has indicated that immunotherapy is a promising treatment option that holds potential as an independent therapeutic strategy, alone or in combination with antimicrobial therapy $[27,28]$. It seems rational to consider that antibody-based immunotherapy prevents MDR-P. aeruginosa burden among the burn patient in whom infection is being established, which ultimately causes high morbidity and mortality. However, inhibition of $P$. aeruginosa virulence factor OprF by IgY antibodies shows a specific antibacterial effect without triggering the development of resistant strains.

In this study, we found that bacterial invasion to A549 cells was inhibited by anti-OprF IgY antibodies, which indicated a key role in reducing the local and systemic distribution of $P$. aeruginosa. It was previously found that high hydrophobicity of anti-OprF IgY antibodies aggregates bacteria, therefore facilitating clearance by the host immune cells [29]. The findings of the current study are consistent with that of our previous report of $25 \%$ invasion of $P$. aeruginosa to A549 cells in the presence of $1 \mathrm{mg}$ anti-PcrV IgY [25].
The observed substantial clinical efficacy of IgY immunotherapy may be associated with interference interactions between pathogen and host epithelial cells [30, 31]. Furthermore, anti-OprF IgGs exhibit potent antibody-dependent complement-mediated killing of the $P$. aeruginosa strain PAO1 [14], and the levels of antibodies correlate with the levels of protection against $P$. aeruginosa in burned mice [16]. In addition, it was suggested that IgY antibodies have inhibitory effects on bacterial pathogenesis and can be considered an adjunct therapy to improve antibiotic action. Thus, anti-OprF IgY antibodies showed a great activity against $P$. aeruginosa and interfered with the $P$. aeruginosa virulence factor to inhibit cell invasion. The moderate inhibitory activity of C-IgY having a nonsignificant reduction in the invasion of $P$. aeruginosa and improvement in the survival of infected mice compared to anti-OprF IgY could be due to the exposition of chickens with $P$. aeruginosa, which is a ubiquitous environmental bacterium and also polyclonal nature of IgY. These findings are consistent with previous studies [25, 29, 32-37].

\section{Conclusion}

In conclusion, these results offer evidence that anti-OprF IgY antibodies can confer protection against burn wound infection caused by $P$. aeruginosa through the inhibition of bacterial invasion to host cells and tissues. Our data show that $P$. aeruginosa-infected treated mice are protected against burn wound sepsis, further supporting the conclusion that IgY against OprF provides approaches to develop a protective treatment. Supposedly, anti-OprF IgY antibodies may be used in combination with antibiotic therapies as an adjunct approach to prevent $P$. aeruginosa infections.

\section{Data Availability}

No data were used to support this study.

\section{Conflicts of Interest}

There are no conflicts of interest.

\section{Acknowledgments}

This work was supported by Shahed University.

\section{References}

[1] I. A. Bahemia, A. Muganza, R. Moore, F. Sahid, and C. N. Menezes, "Microbiology and antibiotic resistance in severe burns patients: a 5 year review in an adult burns unit," Burns, vol. 41, no. 7, pp. 1536-1542, 2015.

[2] E. F. Keen, B. J. Robinson, D. R. Hospenthal et al., "Prevalence of multidrug-resistant organisms recovered at a military burn center," Burns, vol. 36, no. 6, pp. 819-825, 2010.

[3] M. A. Albrecht, M. E. Griffith, C. K. Murray et al., "Impact of Acinetobacter infection on the mortality of burn patients," Journal of the American College of Surgeons, vol. 203, no. 4, pp. 546-550, 2006. 
[4] D. Church, S. Elsayed, O. Reid, B. Winston, and R. Lindsay, "Burn wound infections," Clinical Microbiology Reviews, vol. 19, no. 2, pp. 403-434, 2006.

[5] J. M. Matthews-Greer and H. E. Gilleland, "Outer membrane protein $\mathrm{F}$ (porin) preparation of Pseudomonas aeruginosa as a protective vaccine against heterologous immunotype strains in a burned mouse model," The Journal of Infectious Diseases, vol. 155, no. 6, pp. 1282-1291, 1987.

[6] H. E. Gilleland Jr., L. B. Gilleland, and J. M. Matthews-Greer, "Outer membrane protein F preparation of Pseudomonas aeruginosa as a vaccine against chronic pulmonary infection with heterologous immunotype strains in a rat model," Infection and Immunity, vol. 56, no. 5, pp. 1017-1022, 1988.

[7] E. Bouffartigues, J. A. Moscoso, R. Duchesne et al., "The absence of the Pseudomonas aeruginosa OprF protein leads to increased biofilm formation through variation in c-diGMP level," Frontiers in Microbiology, vol. 6, p. 630, 2015.

[8] L. Fito-Boncompte, A. Chapalain, E. Bouffartigues et al., "Full virulence of Pseudomonas aeruginosa requires OprF," Infection and Immunity, vol. 79, no. 3, pp. 1176-1186, 2011.

[9] L. Peluso, C. de Luca, S. Bozza et al., "Protection against Pseudomonas aeruginosa lung infection in mice by recombinant OprF-pulsed dendritic cell immunization," BMC Microbiology, vol. 10, no. 1, p. 9, 2010.

[10] A. W. Cripps, M. L. Dunkley, D. C. Taylor, S. Cousins, and R. L. Clancy, "Immunity to Pseudomonas aeruginosa induced by OprF following intestinal immunization," Advances in Experimental Medicine and Biology, vol. 371B, pp. 761-763, 1995.

[11] B. M. Price, D. R. Galloway, N. R. Baker, L. B. Gilleland, J. Staczek, and H. E. Gilleland Jr., "Protection against Pseudomonas aeruginosa chronic lung infection in mice by genetic immunization against outer membrane protein $\mathrm{F}(\mathrm{OprF})$ of P. aeruginosa," Infection and Immunity, vol. 69, no. 5, pp. 3510-3515, 2001.

[12] S. Worgall, A. Krause, J. P. Qiu, J. Joh, N. R. Hackett, and R. G. Crystal, "Protective immunity to pseudomonas aeruginosa induced with a capsid-modified adenovirus expressing $\mathrm{P}$. aeruginosa OprF," Journal of Virology, vol. 81, no. 24, pp. 13801-13808, 2007.

[13] U. Baumann, E. Mansouri, and B.-U. Von Specht, "Recombinant OprF-OprI as a vaccine against Pseudomonas aeruginosa infections," Vaccine, vol. 22, no. 7, pp. 840-847, 2004.

[14] E. T. Weimer, S. E. Ervin, D. J. Wozniak, and S. B. Mizel, "Immunization of young African green monkeys with OprF epitope 8-OprI-type A- and B-flagellin fusion proteins promotes the production of protective antibodies against nonmucoid Pseudomonasaeruginosa," Vaccine, vol. 27, no. 48, pp. 6762-6769, 2009.

[15] T. R. Anderson and T. C. Montie, "Flagellar antibody stimulated opsonophagocytosis of Pseudomonas aeruginosa associated with response to either a- or b-type flagellar antigen," Canadian Journal of Microbiology, vol. 35, no. 9, pp. 890894, 1989.

[16] T. R. Anderson and T. C. Montie, "Opsonophagocytosis of Pseudomonas aeruginosa treated with antiflagellar serum," Infection and immunity., vol. 55, no. 12, pp. 3204-3206, 1987.

[17] G. W. Warr, K. E. Magor, and D. A. Higgins, "IgY: clues to the origins of modern antibodies," Immunology Today, vol. 16, no. 8, pp. 392-398, 1995.

[18] M. Tini, U. R. Jewell, G. Camenisch, D. Chilov, and M. Gassmann, "Generation and application of chicken egg- yolk antibodies," Comparative Biochemistry and Physiology. Part A, Molecular \& Integrative Physiology, vol. 131, no. 3, pp. 569-574, 2002.

[19] S. Rahman, K. Higo-Moriguchi, K. W. Htun et al., "Randomized placebo-controlled clinical trial of immunoglobulin $\mathrm{Y}$ as adjunct to standard supportive therapy for rotavirusassociated diarrhea among pediatric patients," Vaccine, vol. 30, no. 31, pp. 4661-4669, 2012.

[20] H. H. Nguyen, T. M. Tumpey, H. J. Park et al., "Prophylactic and therapeutic efficacy of avian antibodies against influenza virus H5N1 and H1N1 in mice," PLoS One, vol. 5, no. 4, article e10152, 2010.

[21] M. G. Wallach, R. J. Webby, F. Islam et al., "Cross-protection of chicken immunoglobulin $\mathrm{Y}$ antibodies against $\mathrm{H} 5 \mathrm{~N} 1$ and H1N1 viruses passively administered in mice," Clinical and Vaccine Immunology, vol. 18, no. 7, pp. 1083-1090, 2011.

[22] E. Nilsson, A. Larsson, H. V. Olesen, P. E. Wejaker, and H. Kollberg, "Good effect of IgY against Pseudomonas aeruginosa infections in cystic fibrosis patients," Pediatric Pulmonology, vol. 43, no. 9, pp. 892-899, 2008.

[23] H. Kollberg, D. Carlander, H. Olesen, P. E. Wejåker, M. Johannesson, and A. Larsson, "Oral administration of specific yolk antibodies (IgY) may prevent Pseudomonas aeruginosa infections in patients with cystic fibrosis: a phase I feasibility study," Pediatric Pulmonology, vol. 35, no. 6, pp. 433-440, 2003.

[24] E. M. Akita and S. Nakai, "Comparison of four purification methods for the production of immunoglobulins from eggs laid by hens immunized with an enterotoxigenic E. coli strain," Journal of Immunological Methods, vol. 160, no. 2, pp. 207214, 1993.

[25] M. Ranjbar, B. Behrouz, F. Norouzi, and S. L. M. Gargari, "Anti-PcrV IgY antibodies protect against Pseudomonas aeruginosa infection in both acute pneumonia and burn wound models," Molecular Immunology, vol. 116, pp. 98-105, 2019.

[26] A. N. Neely, I. A. Holder, and G. D. Warden, "Then and now: studies using a burned mouse model reflect trends in burn research over the past 25 years," Burns: journal of the International Society for Burn Injuries, vol. 25, no. 7, pp. 603-609, 1999.

[27] J.-P. Pirnay, D. De Vos, C. Cochez et al., "Molecular epidemiology of Pseudomonas aeruginosa colonization in a burn unit: persistence of a multidrug-resistant clone and a silver sulfadiazine-resistant clone," Journal of Clinical Microbiology, vol. 41, no. 3, pp. 1192-1202, 2003.

[28] N. P. Singh, R. Goyal, V. Manchanda, S. Das, I. Kaur, and V. Talwar, "Changing trends in bacteriology of burns in the burns unit, Delhi, India," Burns, vol. 29, no. 2, pp. 129-132, 2003.

[29] K. Thomsen, L. Christophersen, T. Bjarnsholt, P. O. Jensen, C. Moser, and N. Hoiby, "Anti-Pseudomonas aeruginosa IgY antibodies induce specific bacterial aggregation and internalization in human polymorphonuclear neutrophils," Infection and Immunity, vol. 83, no. 7, pp. 2686-2693, 2015.

[30] X. Li, L. Wang, Y. Zhen, S. Li, and Y. Xu, "Chicken egg yolk antibodies (IgY) as non-antibiotic production enhancers for use in swine production: a review," Journal of Animal Science and Biotechnology, vol. 6, no. 1, p. 40, 2015.

[31] S. Rahman, S. Van Nguyen, F. C. Icatlo Jr., K. Umeda, and Y. Kodama, "Oral passive IgY-based immunotherapeutics: a novel solution for prevention and treatment of alimentary 
tract diseases," Human Vaccines \& Immunotherapeutics, vol. 9, no. 5, pp. 1039-1048, 2014.

[32] K. Thomsen, L. Christophersen, T. Bjarnsholt, P. Ø. Jensen, C. Moser, and N. Høiby, "Anti- Pseudomonas aeruginosa IgY antibodies augment bacterial clearance in a murine pneumonia model," Journal of Cystic Fibrosis, vol. 15, no. 2, pp. 171-178, 2016.

[33] K. Thomsen, L. Christophersen, P. Ø. Jensen, T. Bjarnsholt, C. Moser, and N. Høiby, "Anti-Pseudomonas aeruginosa IgY antibodies promote bacterial opsonization and augment the phagocytic activity of polymorphonuclear neutrophils," Human Vaccines \& Immunotherapeutics, vol. 12, no. 7, pp. 1690-1699, 2016.

[34] H. Ahmadi, B. Behrouz, G. Irajian, N. Amirmozafari, and S. Naghavi, "Bivalent flagellin immunotherapy protects mice against Pseudomonas aeruginosa infections in both acute pneumonia and burn wound models," Biologicals, vol. 46, pp. 29-37, 2017.

[35] M. Saffari, S. Behbood, G. Irajian, A. Khorshidi, R. Moniri, and B. Behrouz, "Antibodies raised against divalent type b flagellin and pilin provide effective immunotherapy against Pseudomonas aeruginosa infection of mice with burn wounds," Biologicals, vol. 45, pp. 20-26, 2017.

[36] B. Behrouz, N. Amirmozafari, N. Khoramabadi, M. Bahroudi, P. Legaee, and M. Mahdavi, "Cloning, expression, and purification of Pseudomonas aeruginosa flagellin, and characterization of the elicited anti-flagellin antibody," Iranian Red Crescent Medical Journal, vol. 18, no. 6, p. e28271, 2016.

[37] M. Mousavi, B. Behrouz, G. Irajian, M. Mahdavi, F. Korpi, and M. Motamedifar, "Passive immunization against Pseudomonas aeruginosa recombinant PilA in a murine burn wound model," Microbial Pathogenesis, vol. 101, pp. 83-88, 2016. 